\title{
Multi-factor analysis of failure of renal replacement therapy in acute renal failure developed after cardiac surgery
}

\author{
Pawel Nawrocki ${ }^{1}$, Ireneusz Szwedo ${ }^{2}$, Joanna Tyc ${ }^{3}$, Anna Hawrysz ${ }^{3}$, Kamila Janiak ${ }^{3}$, Romuald Cichoń ${ }^{4}$ \\ ${ }^{1}$ Department of Cardiac Surgery, Wroclaw Medical University, Wroclaw, Poland \\ ${ }^{2}$ Lower Silesian Centre for Heart Diseases MEDINET, Wroclaw, Poland \\ ${ }^{3}$ Students' Scientific Association at the Lower Silesian Centre for Heart Diseases MEDINET, Wroclaw, Poland \\ ${ }^{4}$ Department of Cardiac Surgery of Chair and Department of Cardiology, Faculty of Medicine, Medical University of Warsaw, \\ Poland
}

Kardiochirurgia i Torakochirurgia Polska 2015; 12 (3): 195-198

\begin{abstract}
Introduction: Acute renal failure (ARF) is a rare (2-15\%), but severe complication of cardiac surgery with overall mortality reaching $40-80 \%$. In order to save patients' lives they are treated with renal replacement therapy (RRT). The aim of our study was to assess the impact of different perioperative factors on mortality among patients treated with RRT because of acute renal failure, which occurred as a complication of a heart surgery.

Material and methods: Retrospective analysis included $45 \mathrm{pa}$ tients, operated in the years 2009-2013, who underwent renal replacement therapy in order to treat postoperative ARF. The perioperative factors were analysed in two groups: group 1 - patients who died before discharge; and group 2 - those who survived until hospital discharge.

Results: Forty-five of 3509 cardiac surgical patients (1.25\%) required RRT after the surgery. A total of 23 (51.11\%) died before discharge (group 1). Patients in group 1 were characterised by older age (70.21 vs. 67 years), higher mean EuroSCORE value (9.28 vs. 7.15$)$ ( $p<0.05)$, higher percentage of concomitant surgery $(63.63 \%$ vs. $28.57 \%)(p<0.05)$ and of admission of catecholamines in the postoperative period (100\% vs. $68.42 \%$ ) $(p<0.005)$, and higher mean urea blood level prior to RRT initiation (156.65 vs. $102.54 \mathrm{mg} / \mathrm{dl})(p<0.05)$.

Conclusions: The statistically relevant death predictors proved to be: high EuroSCORE, concomitant surgery, and high urea level at RRT initiation and admission of catecholamines in the postoperative period. After conformation in further studies, those factors may prove useful in stratification of death risk among surgical patients requiring RRT.
\end{abstract}

Key words: renal replacement therapy, acute renal failure.

\section{Streszczenie}

Wstęp: Ostra niewydolność nerek jest rzadkim (2-15\%), ale bardzo niebezpiecznym powikłaniem operacji kardiochirurgicznych, obarczonym śmiertelnością rzędu 40-80\%. W celu ratowania życia chorzy poddawani są zabiegom dializoterapii. Celem pracy była ocena wpływu określonych czynników na śmiertelność wśród pacjentów kardiochirurgicznych poddanych terapii nerkozastępczej z powodu ostrej pooperacyjnej niewydolności nerek. Materiat i metody: Retrospektywnej analizie poddano dane 45 pacjentów operowanych kardiochirurgicznie w latach 2009-2013, u których włączono terapię nerkozastępczą z powodu pooperacyjnej ostrej niewydolności nerek. Analizowano związek czynników okołooperacyjnych ze śmiertelnością, dzieląc przy tym pacjentów na grupę nr 1 - zmarłych w trakcie leczenia; oraz grupę nr 2 - tych, którzy przeżyli do momentu wypisania ze szpitala.

Wyniki: Spośród 3509 pacjentów 45 (1,25\%) wymagało włączenia leczenia nerkozastępczego po operacji. Przed wypisem ze szpitala zmarły 23 osoby (51,11\%) (grupa nr 1). Pacjentów z tej grupy charakteryzował starszy średni wiek (70,21 vs 67 lat) i wyższy średni wynik w skali EuroSCORE $(9,28$ vs 7,15$)$ ( $p<0,05)$, częściej przechodzili zabieg złożony $(63,63 \%$ vs $28,57 \%)(p<0,05)$, częściej wymagali podawania katecholamin w okresie pooperacyjnym $(100 \%$ vs $68,42 \%)(p<0,005)$ oraz mieli większe średnie stężenie mocznika we krwi przed rozpoczęciem dializ $(156,65$ vs 102,54 mg/dl) $(p<0,05)$.

Wnioski: Wysoki wynik w skali EuroSCORE, zabieg złożony, duże stężenie mocznika we krwi przy włączaniu terapii nerkozastępczej oraz potrzeba użycia katecholamin w okresie pooperacyjnym okazały się statystycznie istotnymi czynnikami zwiększającymi śmiertelność w badanej populacji chorych. Wymienione czynniki mogą posłużyć do identyfikacji pacjentów o zwiększonym ryzyku zgonu, wymaga to jednak potwierdzenia w dalszych badaniach na szerszej populacji chorych.

Słowa kluczowe: terapia nerkozastępcza, ostra niewydolność nerek. 


\section{Introduction}

Acute renal failure (ARF) requiring the use of renal replacement therapy (RRT) is a rare, but very severe complication of cardiac surgery. It is a sudden renal insufficiency accompanied by higher creatinine blood level and oliguria, defined as urine output $<0.5 \mathrm{ml} / \mathrm{kg}$ per hour. Its incidence varies from $2 \%$ to $15 \%$ with overall mortality as high as $40 \%$ to $80 \%$, highlighting the importance of this issue [1, 2]. Moreover, ARF has been proven to be an independent predictor of death after cardiac surgery [3]. One of the main problems faced by physicians in everyday practice is a lack of consensus on the diagnostic criteria for ARF and the optimal time to initiate RRT. In this study ARF was considered in the case of oliguria or if there was a clinical need for RRT initiation (e.g. uncontrollable hyperkalaemia).

The aim of our study was to find differences between two observed groups of patients, who underwent dialysis as a treatment for ARF after cardiac surgery: those who died during treatment (group 1) and those who survived until hospital discharge (group 2). Modifiable and unmodifiable factors connected with heart operation were analysed in order to find predictors of mortality in the examined population.

\section{Material and methods}

The retrospective analysis included 45 patients diagnosed with ARF after cardiac surgery and subsequently treated with RRT in our clinic in years 2009 to 2013. Data was obtained from patients' records as well as the hospital's cardiac surgery database.

Collected information was divided into three categories: I. Preoperative factors: patient's sex, age, weight, height, body mass index (BMI), ejection fraction (EF), EuroSCORE value, creatinine blood level, estimated glomerular filtration rate (eGFR) on admission, recent myocardial infarction ( $\leq 90$ days before surgery) or angiography procedure ( $\leq 14$ days before surgery), history of diabetes, hypertension, and heart failure.

II. Factors associated with the surgery: procedure other than coronary artery bypass graft surgery (CABG), reoperation, concomitant surgery (e.g. CABG plus aortic valve replacement), use of extracorporeal circulation (ECC), time of ECC, time of cross clamp, and use of catecholamines and intra-aortic balloon pump (IABP) during surgery.

III. Postoperative factors: respiratory support ( $>4$ days after surgery), drainage (> $1000 \mathrm{ml} / 24 \mathrm{~h}$ ), day of RRT initiation, creatinine, urea and potassium blood levels at RRT initiation, bacteremia and maximal C-reactive protein (CRP) level, and administration of catecholamines and IABP in the postoperative period.

Statistical analysis was performed by Stat-Soft, Inc. STATISTICA (data analysis software system) version 12.0, using $\chi^{2}$ test, $t$-test, and $U$ Mann-Whitney test.

\section{Results}

In total $1.25 \%$ of patients treated in our clinic in years 2009-2013 (45 out of 3590 patients) developed ARF requir- ing RRT after cardiac surgery. Twenty-three (51.11\%) died before discharge. As shown in Table I, patients who died during treatment (group 1) were older and had higher mean $\mathrm{BMI}$ value than those who survived until discharge. Before the operation patients in group 1 had lower mean ejection fraction (EF) value; in this group we also observed higher percentage of patients diagnosed with heart failure, hypertension, or recent ( $\leq 90$ days before surgery) myocardial infarction and higher percentage of angiography procedures ( $\leq 14$ days before surgery). Surprisingly, patients in group 1 showed lower mean creatinine blood level values. However, none of those findings proved to be of statistical significance. After the statistical analysis the only significant preoperative death risk factor proved to be high score on the EuroSCORE scale, with a mean value of 9.28 in group 1 (survivors) vs. 7.15 in group $2(p<0.05)$.

When it comes to factors associated with the surgery, only the higher percentage of concomitant cardiac surgeries (e.g. CABG and concomitant aortic valve replacement) in group 1 (63.63\% vs. $28.57 \%)$ turned out to be a statistically significant death predictor $(p<0.05)$. Patients in group 1 were more often reoperated, had procedure other than $C A B G$, and a higher percentage of surgeries in extracorporeal circulation (ECC). In this group the time of ECC and the cross clamp time were also longer. Administration of catecholamines and use of IABP during the operation were less frequent in group 1.

In the category of postoperative factors, admission of catecholamines (postop.) (100\% vs. 68.42\%) $(p<0.005)$ and higher blood urea values at RRT initiation $(156.65 \mathrm{mg} / \mathrm{dl}$ vs. $102.54 \mathrm{mg} / \mathrm{dl})(p<0.05)$ proved to be statistically significant death predictors. A higher percentage of patients in group 1 required administration of catecholamines (postop.), IABP (postop.), respiratory support (> 4 days), and drainage $>1000 \mathrm{ml} / 24 \mathrm{~h}$. They showed higher incidence of bacteraemia and higher maximal CRP levels. Surprisingly, in group 1 , RRT was started earlier (4.5 vs. 5.47 day) with lower mean blood levels of urea, creatinine, and potassium prior to its initiation (Table I).

\section{Discussion}

Although there are many studies that have focused on the problem of ARF after cardiac surgery, there is still no consensus on a clear definition or precise pathophysiological mechanisms, risk factors, and practical guidelines concerning ARF patients, which in turn leads to poor outcomes.

Prerenal acute kidney insufficiency is caused by a decline in renal blood flow. It is not connected with disturbance of kidneys themselves, as in the case of renal ARF. Hypoperfusion of renal medulla, caused by vasoconstriction of renal arterioles and redistribution of blood flow within kidneys, seems to be the most likely mechanism leading to postoperative ARF. Therefore, if rapid and effective treatment reinforcing renal blood flow is undertaken the filtration will increase as well as the urine output. That is why fast diagnosis and treatment is of utmost importance to avoid ARF [4-6]. 
Tab. I. Preoperative, perioperative and postoperative data in groups 1 and 2

\begin{tabular}{|c|c|c|c|}
\hline & $\begin{array}{c}\text { Group } 1 \\
\text { (non-survivors) } \\
n=23\end{array}$ & $\begin{array}{c}\text { Group } 2 \\
\text { (survivors) } \\
n=22\end{array}$ & $p$ value \\
\hline \multicolumn{4}{|l|}{ Preoperative factors } \\
\hline Age (years) ${ }^{a}$ & 70.21 & 67 & 0.3473 \\
\hline $\mathrm{BMI}^{\mathrm{a}}$ & 28.22 & 26.49 & 0.2808 \\
\hline Recent myocardial infarction ( $\leq 90$ days before surgery) ${ }^{b}$ & $47.83 \%$ & $31.81 \%$ & 0.2732 \\
\hline Blood creatinine level on admission $[\mathrm{mg} / \mathrm{dll}]^{a}$ & 1.526 & 2.20 & 0.2644 \\
\hline eGFR on admission ${ }^{a}$ & 59.72 & 59.17 & 0.9251 \\
\hline Diabetes $^{b}$ & $39.13 \%$ & $45.45 \%$ & 0.6676 \\
\hline Hypertension ${ }^{b}$ & $86.95 \%$ & $85.71 \%$ & 0.9045 \\
\hline Heart failure ${ }^{b}$ & $59.09 \%$ & $47.61 \%$ & 0.4509 \\
\hline Ejection fraction $(E F)^{a}$ & 48.75 & 51.2 & 0.5709 \\
\hline Angiography ( $\leq 14$ days before surgery $)^{b}$ & $45 \%$ & $42.85 \%$ & 0.8901 \\
\hline EuroSCORE ${ }^{a}$ & 9.28 & 7.15 & $0.0422^{*}$ \\
\hline \multicolumn{4}{|l|}{ Factors associated with the procedure } \\
\hline Procedure other than $\mathrm{CABG}^{\mathrm{b}}$ & $63.63 \%$ & $40.9 \%$ & 0.1312 \\
\hline Reoperation ${ }^{b}$ & $27.27 \%$ & $23.85 \%$ & 0.7947 \\
\hline Concomitant surgery ${ }^{b}$ & $63.63 \%$ & $28.57 \%$ & $0.0212^{*}$ \\
\hline Use of ECC & $86.95 \%$ & $76.19 \%$ & 0.3550 \\
\hline Time of ECC $[\mathrm{min}]^{a}$ & 147.9 & 127.56 & 0.3727 \\
\hline Time of cross clamp [min] ${ }^{a}$ & 81 & 70.66 & 0.6769 \\
\hline Catecholamines (in OR) $)^{b}$ & $26.08 \%$ & $33.33 \%$ & 0.5987 \\
\hline IABP (in OR) $)^{b}$ & $17.39 \%$ & $20 \%$ & 0.8265 \\
\hline \multicolumn{4}{|l|}{ Postoperative factors } \\
\hline Respiratory support (> 4 days) & $68.18 \%$ & $52.38 \%$ & 0.2895 \\
\hline Drainage $(>1000 \mathrm{ml} / 24 \mathrm{~h})^{\mathrm{b}}$ & $54.54 \%$ & $45 \%$ & 0.5366 \\
\hline Day of RRT initiation (after surgery)a & 4.5 & 5.47 & 0.8554 \\
\hline Blood creatinine level [mg/dl] ${ }^{a}$ & 3.36 & 3.84 & 0.2281 \\
\hline Blood urea level [mg/dl] ${ }^{a}$ & 156.65 & 102.54 & $0.0305^{*}$ \\
\hline Blood potassium level at RRT initiation [mmol//] ${ }^{a}$ & 4.76 & 4.87 & 0.7388 \\
\hline Bacteraemia $^{b}$ & $19 \%$ & $11.11 \%$ & 0.4935 \\
\hline Maximal CRP level $\left[\mathrm{mg} / \mathrm{l}^{\mathrm{a}}\right.$ & 198.77 & 148.15 & 0.1891 \\
\hline Catecholamines (postoperative) ${ }^{b}$ & $100 \%$ & $68.42 \%$ & $0.0043^{*}$ \\
\hline IABP (postoperative) ${ }^{\mathrm{b}}$ & $27.27 \%$ & $21.05 \%$ & 0.6437 \\
\hline
\end{tabular}

'Denotes statistical significance.

a Mean value in the analysed group of patients

bercentage of patients in the analysed group

BMI - body mass index, eGFR - estimated glomerular filtration rate, CABG - coronary artery bypass graft, ECC - extracorporeal circulation, OR - operating room, IABP - intra-aortic balloon pump, RRT - renal replacement therapy, CRP - C reactive protein 
Nowadays, patients with acute kidney injury are often ordinated with RRT only after significant disturbance of acid-alkaline balance. The tendency is to delay the process of dialysis as long as the imbalance does not occur in order to avoid side effects of RRT. The presentation of AKI is connected with individual predisposition [7].

There is a high number of risk factors mentioned in literature, suggested to provoke ARF after heart surgery, including: age [8], diabetes [9-12], previous cardiovascular surgery [4], CPB time [13], duration of cross-clamp time [14], generalised inflammatory response as a consequence of the CPB circuit [15], and exposure to iodine dye (coronarography) a short time before surgery [16]. However, analysis of those variables did not change any statistically important differences between group 1 and 2 .

On the other hand, EuroSCORE or the need of vasopressor support after surgery [17] proved to be statistically meaningful mortality predictors in the group of patients treated with RRT. However, those factors are generally associated with higher death risk in all patients undergoing surgery, not peculiarly those diagnosed with ARF.

Surprisingly, there was a relevant difference in urea level at RRT initiation without a significant discrepancy in creatinine level. Therefore, level of urea should not be underestimated or omitted when creatinine level is within normal limits. Also, the fact of undergoing a concomitant surgery turned out to be a statistically important factor affecting the patients' mortality rate. However, parameters such as CPB use, CPB time, or cross clamp time did not prove to be of statistical significance.

\section{Limitations}

A relatively small group of patients and lack of followup observation after discharge (only short-term results) may have been limitations of our study.

\section{Conclusions}

Statistically significant death predictors in the group of patients treated with RRT because of acute kidney insufficiency that occurred after cardiac surgery turned out to be: high EuroSCORE, concomitant surgery, high urea level at RRT initiation, and admission of catecholamines in the postoperative period. The presented observations should be further investigated on a larger group of patients, followed by the creation of practical guidelines on the treatment of postoperative ARF and the place of renal replacement therapy within that process.

\section{Disclosure}

Authors report no conflict of interest.

\section{References}

1. Sirivella S, Gielchinsky I, Parsonnet V. Mannitol, furosemide and dopamine infusion in post-operative renal failure complicating cardiac surgery. Ann Thorac Surg 2000; 69: 501-506.

2. Lassnigg A, Donner E, Grubhofer G, Presterl E, Druml W, Hiesmayr M. Lack of reno-protective effects of dopamine and furosemide during cardiac surgery. J Am Soc Nephrol 2000; 11: 97-104.

3. Chertow GM, Levy EM, Hammermeister KE, Grover F, Daley J. Independent association between acute renal failure and mortality following cardiac surgery. Am J Med 1998; 104: 343-348.

4. De Moreas Lobo EM, Burdmann EA, Abdulkader RCRM. Renal function changes after elective cardiac surgery with cardiopulmonary bypass. Renal Failure 2000; 22: 487-497.

5. Luckraz H, Gravenor MB, George R, Taylor S, Williams A, Ashraf S, Argano V, Youhana A. Long and short-term outcomes in patients requiring continuous renal replacement therapy post cardiopulmonary bypass. Eur J Cardiothorac Surg 2005; 27: 906-909.

6. Myśliwiec M. Acute kidney injury after surgery in cardio-pulmonary bypass. Nephrol Dial Pol 2011; 15: 194-196.

7. Kidney Disease: Improving Global Outcomes (KDIGO) Acute Kidney Injury Work Group KDIGO Clinical Practice Guideline for Acute Kidney Injury. Kidney Int Suppl 2012; 2: 1-138.

8. Kilo J, Margreiter JE, Ruttmann E, Laufer G, Bonatti JO. Slightly elevated serum creatinine predicts renal failure requiring hemofiltration after cardiac surgery. Heart Surg Forum 2005; 8: 34-38.

9. Pflueger AC, Schenk F, Osswald $H$. Increased sensitivity of the renal vasculature to adenosine in streptozotocin-induced diabetes mellitus rats. Am J Physiol 1995; 269: 529-535.

10. Pflueger AC, Gross JM, Knox FG. Adenosine-induced renal vasoconstriction in diabetes mellitus rats: role of prostaglandins. Am J Physiol 1999; 277: 1410-1417.

11. Pflueger AC, Osswald H, Knox FG. Adenosine-induced renal vasoconstriction in diabetes mellitus rats: role of nitric oxide. Am J Physiol 1999; 276 : 340-346.

12. Pflueger AC, Larson TS, Hagl S, Knox FG. Role of nitric oxide in intrarenal hemodynamics in experimental diabetes mellitus in rats. Am J Physiol 1999; 277: 725-733.

13. Doddakula K, Al-Sarraf N, Gately K, Hughes A, Tolan M, Young V, McGovern E. Predictors of acute renal failure requiring renal replacement therapy post cardiac surgery in patients with preoperatively normal renal function. Interact Cardiovasc Thorac Surg 2007; 6: 314-318.

14. Zhu J, Yin R, Shao H, Dong G, Luo L, Jing H. N-acetylcysteine to ameliorate acute renal injury in a rat cardiopulmonary bypass model. J Thorac Cardiovasc Surg 2007; 133: 696-703.

15. Gu YJ, de Vries AJ, Boonstra PW, Van Oeveren W. Leukocyte depletion results in improved lung function and reduced inflammatory response after cardiac surgery. J Thorac Cardiovasc Surg 1996; 112: 494-500.

16. Groetzner J, Kaczmarek I, Landwehr P, Mueller M, Daebritz S, Lamm P, Meiser B, Reichart B. Renal recovery after conversion to a calcineurin inhibitor-free immunosuppression in late cardiac transplant recipients. Eur J Cardiothorac Surg 2004; 25: 333-341.

17. Lombardi R, Ferreiro A. Risk factors profile for acute kidney injury after cardiac surgery is different according to the level of baseline renal function. Ren Fail 2008; 30: 155-160. 